Jakov Ivković

Ivan Vukoja

Lana Njavro

Danko Relić

Olga Plazibat

Ana Asančaić

Jadranka Božikov
UDK: 614(497.5)

DOI: http://doi.org/10.21857/ydkx2c3ng9

Stručni članak

Rukopis prihvaćen za tisak: 16.12.2015.

\title{
ŠEST GODINA JAVNOZDRAVSTVENIH AKTIVNOSTI UDRUGE NARODNOG ZDRAVLJA “ANDRIJA ŠTAMPAR"
}

\begin{abstract}
Sažetak
Udruga narodnog zdravlja "Andrija Štampar“ (u daljnjem tekstu Udruga) osnovana je 2009. godine na Medicinskom fakultetu Sveučilišta u Zagrebu. Glavni ciljevi Udruge jesu promocija važnosti javnog zdravstva i narodnog zdravlja te humanosti, promocija zdravih stilova života i prevencija bolesti. Udruga promiče medicinu usmjerenu na osobu te se snažno zalaže za prevenciju svih oblika nasilja, posebno međuvršnjačkog nasilja, uz promicanje socijalne jednakosti i blagostanja. Kroz multidisciplinarni pristup, Udruga okuplja studente medicine i liječnike i druge akademske građane.

Članovi Udruge promiču učenja Andrije Štampara koji je isticao kako čovijek nije samo fizičko i mentalno biće, već jednako tako duhovno i socijalno. Zbog toga su sve aktivnosti Udruge prožete Štamparovim načelima, a posebno ističemo tradicionalne projekte "Štamparovi dani“, „Budi cool, ne budi bully“ i „Zdravlje svima“ te projekte obilježavanja Svjetskog dana mozga i Svjetskog dana moždanog udara te obilježavanja drugih javnozdravstvenih datuma s partnerskim organizacijama.

Tijekom šest godina u akcijama i projektima Udruge aktivno je sudjelovalo više od 300 volontera s više od 60.000 volonterskih sati te s preko 3.000 uključenih sudionika.
\end{abstract}

Ključne riječi: Udruga narodnog zdravlja "Andrija Štampar"; javno zdravstvo; humanost; Andrija Štampar; multidisciplinarni pristup; volonteri.

\section{Uvod}

Ljudi svakodnevno koriste blagodati modernog života. No činjenica je da moderni životni stil ima i svoje negativne strane, a to je prije svega nedovoljan odmor i san, nezdrava prehrana i pretjeran unos soli, nedovoljna tjelesna aktivnost, pušenje, pretjerana konzumacija alkohola, te danas nezaobilazna izloženost stresu. 
S obzirom na utjecaj životnog stila na zdravlje ${ }^{1-5}$ te demografsko starenje stanovništva u modernim zemljama, kao i Republici Hrvatskoj, jasno je kako se suočavamo s porastom smrtnosti zbog kroničnih nezaraznih bolesti, poput kardiovaskularnih bolesti, cerebrovaskularnih bolesti, karcinoma, šećerne bolesti i kroničnih plućnih bolesti. Prema podacima Svjetske zdravstvene organizacije 2012. godine u svijetu je bilo 38 milijuna smrtnih ishoda zbog kroničnih nezaraznih bolesti, od kojih $40 \%$ u osoba mlađih od 70 godina, dok su projekcije da će broj smrtnih ishoda zbog navedenih bolesti 2030. godine biti 52 milijuna ${ }^{7}$

Premda na neke od čimbenika rizika za razvoj bolesti poput dobi, spola te obiteljske anamneze pojedinaca ne možemo utjecati, postoje i oni čimbenici na koje uglavnom možemo utjecati poput nepravilne prehrane, visokog krvnog tlaka i povećanog unosa soli, povišenog kolesterola, šećerne bolesti i loše regulacije glikemije, pretilosti, pušenja, pretjerane konzumacije alkohola te nedovoljne tjelesne aktivnosti. Regulacijom ovih čimbenika rizika možemo smanjiti pojavu kroničnih bolesti, te u konačnici nastale invalidnosti i smrtnih ishoda. U prilog tome govore razni izvori, a izdvojit ćemo primjer Japana gdje je vlada zbog velike incidencije cerebrovaskularnog inzulta pokrenula nacionalni program s ciljem redukcije povišenog krvnog tlaka i cerebrovaskularnog inzulta u populaciji ${ }^{8}$. Provođenjem sistematskih pregleda, poticanjem na redovito uzimanje antihipertenzivne terapije $u$ hipertoničara, tjelovježbom i organizacijom zajedničkih šetnji, edukacijama o zdravoj prehrani, poticanjem na smanjenje unosa soli te organizacijom ljetnih škola zdravog kuhanja za djecu, incidencija cerebrovaskularnog inzulta smanjena je za $85 \%$ u odnosu na 60 -te godine prošlog stoljeća. Utjecaj regulacije krvnog tlaka kroz preventivne programe na cerebrovaskularni inzult potvrdilo je i istraživanje provedeno u Japanu na dvije ruralne zajednice, kojim je utvrđeno da se incidencija cerebrovaskularnog inzulta u muškaraca snizila za $75 \%$ u zajednici s razvijenim preventivnim programom koji je uključivao „screening“ mjerenje krvnog tlaka, regulaciju hipertenzije medikamentima, edukaciju populacije, promociju zdrave prehrane te smanjenje unosa soli, u odnosu na $29 \%$ smanjenje incidencije u zajednici koja je provodila „screening“ mjerenje krvnog tlaka, ali bez drugih organiziranih aktivnosti ${ }^{9}$.

\section{UDRUGA NARODNOG ZDRAVLJA “ANDRIJA ŠTAMPAR”}

Udruga narodnog zdravlja Andrija Štampar (u daljnjem tekstu Udruga) osnovana je u siječnju 2009. godine s ciljem podizanja svijesti o važnosti javnog zdravstva i narodnog zdravlja, promocije zdravih stilova života i prevencije bolesti.

Kroz multidisciplinarni pristup, Udruga okuplja liječnike raznih usmjerenja, studente medicine, i druge akademske građane koji dijele iste ciljeve i shvaćaju važ- 
nost prevencije bolesti. Članovi Udruge promiču učenje Andrije Štampara kako čovjek nije samo fizičko i mentalno biće, već jednako tako duhovno i socijalno.

Mišljenja smo da preventivne programe treba provoditi od najranijih uzrasta, jer će se pozitivne životne navike usvojene u mladosti pozitivno odraziti na zdravlje i život svakog pojedinca, dok će se loše navike u kasnijim godinama puno teže ispravljati, a u konačnici mogu dovesti do razvoja bolesti. Međutim, $s$ obzirom na to da u populaciji postoje ljudi s već razvijenim bolestima poput hipertenzije, šećerne bolesti ili hiperlipidemije, koje mogu dovesti do daljnih neželjenih ishoda, primjerice infarkta srca ili cerebrovaskularnog inzulta, te time do invalidnosti ili smrtnog ishoda, Udruga osim preventivnim aktivnostima puno pažnje posvećuje promicanju svijesti o potrebi trajnog liječenja već dijagnosticiranih kroničnih bolesti koje su često nedovoljno medikamentozno tretirane ${ }^{10}$.

\section{AKTIVNOSTI UDRUGE}

Sukladno ciljevima Udruge, članovi od samog osnivanja kontinuirano djeluju na polju unaprjeđenja zdravlja i prevenciji bolesti. Organiziramo i s partnerskim organizacijama provodimo niz edukativnih i preventivnih aktivnosti, od kojih ćemo neke prikazati u nastavku:

\section{Stručno-edukacijski simpozij Štamparovi dani}

Projekt pokrenut u prosincu 2009. godine temeljni je projekt Udruge. Štamparovi dani su troetapni događaj koji se održava u Požeško-slavonskoj županiji, kraju iz kojeg potječe velikan hrvatske i svjetske medicine - Andrija Štampar.

Prva faza projekta obuhvaća mjerenje krvnog tlaka i šećera populaciji u tom kraju, provođenje anketnog ispitivanja o kvaliteti života, kao i davanje specifičnih savjeta o prevenciji i kontroli bolesti u skladu s mogućnostima na terenu, druga faza su edukativna predavanja školskoj populaciji, kao i provedba radionica s ciljem prevencije međuvršnjačkog nasilja i promocije zdravlja te zdravih stilova života, a treća faza obuhvaća predavanja eminentnih stručnjaka usmjerena edukaciji zdravstvenih djelatnika.

Cijeli projekt prožet je mišlju kako se osobu i pacijenta ne smije promatrati isključivo kroz prizmu njegove bolesti te ga se na istu simplificirati, već da svaka osoba treba biti promatrana u jedinstvu svog fizičkog, psihičkog, socijalnog i duhovnog bića. Također, kroz manifestaciju ovog tipa studenti koji sudjeluju u provedbi projekta uviđaju prednosti i nužnost ovakvog načina razmišljanja i djelovanja, jer se time dugoročno postiže poboljšanje odnosa budućih zdravstvenih djelatnika u shvaćanju populacije i sustava zdravstva, prvenstveno na mikrorazinama, a potom i globalno.

Simpozij je priznat od strane Sveučilišta u Zagrebu, kao jedan od kvalitetnijih projekata iz biomedicinskog područja, a podršku od prvog simpozija do danas pru- 
žaju Medicinski fakultet Sveučilišta u Zagrebu, Škola narodnog zdravlja "Andrija Štampar" te jedinice lokalne i regionalne samouprave Požeško-slavonske županije.

\section{Budi cool ne budi bully}

Bullying se definira kao ponašanje kojem je cilj da se nekog povrijedi ili da mu se nanese šteta. Karakterizira ga ponavljanje te razlika u tjelesnoj i psihološkoj snazi između počinitelja zlostavljanja i žrtve koja je izložena zlostavljajućem ponašanju ${ }^{11}$.

Članovi Udruge od 2009. godine aktivno djeluju na prevenciji međuvršnjačkog nasilja u sklopu projekta „Budi cool ne budi bully“, koji se provodi u osnovnoškolskim razrednim odjeljenjima. Riječ je o interaktivnim radionicama uz moderiranje dvaju članova Udruge, tijekom kojih kroz usku suradnju s ciljanom populacijom djelujemo znanstveno dokazanim, pedagoškim metodama. Učenicima se dijeli i brošura s prigodnim tekstovima o međuvršnjačkom nasilju, ponašanjima i aktivnostima koje ga preveniraju te se ispunjava anketni listić o bullyingu u školi. Analizom podataka dolazimo do zaključka da djeca razumiju pojam međuvršnjačkog nasilja te su svjedoci istog u svom okruženju. Primjerice u osnovnoj školi u Pleternici, gdje je radionicom bilo obuhvaćeno 106 djece, čak 19\% njih je bilo žrtvom bullyinga, dok se dodatnih $12 \%$ nije izjasnilo na postavljano pitanje $\mathrm{e}^{12}$.

Ovim projektom, osim same edukacije o tome što je bullying, pokušaja prevencije, te javne osude istog, cilj je i potaknuti pravodobno prepoznavanje i reagiranje ukoliko međuvršnjačko nasilje postoji, kako bi se spriječili „ožiljci“ koji će obilježiti ostatak nečijeg života.

Edukaciju dugujemo prof. dr. sc. Vesni Jureši i Školi narodnog zdravlja „Andrija Štampar" Medicinskog fakulteta Sveučilišta u Zagrebu.

\section{Croatian Student Summit}

CROatian Student Summit (CROSS) znanstveni je kongres s međunarodnim sudjelovanjem, koji okuplja studente i mlade znanstvenike biomedicinskog područja. Projekt je pokrenuo Studentski zbor Medicinskog fakulteta Sveučilišta u Zagrebu 2005. godine. Udruga sudjeluje u organizaciji kongresa od 2010. godine, a među aktivnim članstvom su i neki od začetnika kongresa.

Cilj je kongresa omogućiti studentima i mladim znanstvenicima da na početku svoje karijere nauče važnost znanstvene aktivnosti i sudjelovanja na stručnim i znanstvenim događanjima, kao dijela cjeloživotnog učenja koje će im donijeti nove spoznaje i olakšati svakodnevni rad. Osim toga studentima se predočuje spoznaja kako niti jedna informacija dobivena istraživanjem neće biti korisna dok ne postane javna i dostupna drugim istraživačima. 
Kongres je prepoznat i od strane Sveučilišta u Zagrebu te je kao potvrda dobrog rada organizatorima dodijeljena posebna Rektorova nagrada.

\section{Zdravlje svima}

Zdravlje svima projekt je koji je pokrenut s partnerima sredinom 2014. godine. Cilj projekta promocija je zdravlja provedbom aktivnosti, osmišljenih po načelima koja je zagovarao Andrija Štampar, holističkim pristupom i djelovanjem zdravstvenih radnika među populacijom, a ne samo kroz zdravstvene ustanove.

Kroz projekt se prati zdravstveno stanje i kvaliteta života stanovništva te promiče zdravlje i zdravi stilovi života. Obuhvaća stanovnike Požeško-slavonske županije, uglavnom njezinog ruralnog područja te stanovnike Grada Zagreba, u dobi od 16 godina na više.

Za potrebe projekta koristi se Hrvatska zdravstvena anketa koju je na korištenje ustupila Škola narodnog zdravlja Andrija Štampar te tablica za procjenu rizika od moždanog udara, koju je na korištenje ustupilo Hrvatsko društvo za prevenciju moždanog udara. Analizom podataka utvrdit će se u kojoj mjeri ispitano stanovništvo vodi brigu o svom zdravlju, prisutnost čimbenika rizika za razvoj bolesti poput pušenja, konzumacije alkohola, tjelesne neaktivnosti, te koliko su zastupljene kronične bolesti poput šećerne bolesti, povišenog krvnog tlaka, hiperlipidemije i drugih. Prilikom anketiranja individualiziranim pristupom zainteresirane ispitanike podučava se kako smanjiti prisutnost čimbenika rizika brojnih bolesti. Dio projekta je i organizacija interaktivnih radionica na kojima se ciljana populacija upoznaje s najčešćim zdravstvenim problemima te savjetuje o prevenciji i mogućnostima liječenja istih. Nezaobilazni dio aktivnosti Udruge inače, pa tako i ovdje, edukacija je medicinskih profesionalaca. Posebno bismo izdvojili međunarodni Simpozij palijativne skrbi i medicine, održan u prosincu 2014. godine, na kojem je u dva dana ukupno sudjelovalo 255 aktivnih i pasivnih sudionika. Na ostalim simpozijima u čijoj je organizaciji Udruga sudjelovala nazočilo je dodatnih 150 zdravstvenih profesionalaca (liječnika, medicinskih sestara, socijalnih radnika). Inače je do sada tijekom provedbe projekta anketiranjem obuhvaćeno 788 ljudi, radionicama za stariju i srednju dob 360, dok je na održanim radionicama za mlade prisustvovalo 278 ljudi. U provedbi projekta, uz 4 izvoditelja projekta, uključeno je do sada 37 volontera i 46 volontera predavača.

U tijeku su daljnje aktivnosti, kojima ćemo i dalje nastojati osvijestiti građanstvo o zdravim životnim stilovima koji doprinose kvalitetnijem životu i životu bez bolesti. 


\section{Zaključak}

Kronične nezarazne bolesti glavni su uzrok smrtnosti danas. Budući da je riječ o bolestima s multifaktorijalnim uzrocima nastanka, kronične bolesti ne možemo iskorijeniti, no svakako možemo utjecati na smanjenje njihove incidencije te u konačnici reducirati broj smrtnih ishoda koje prouzroče, ali i broj prouzročenih invalidnosti, čije socioekonomske posljedice osjeća cijela zajednica.

Individualni angažman u promjeni životnog stila bitan je, čemu pridonose i javnozdravstvene aktivnosti koje organizira Udruga narodnog zdravlja Andrija Štampar te niz drugih organizacija na području Republike Hrvatske. Međutim, za postizanje bitnijeg uspjeha na području prevencije bolesti i očuvanja narodnog zdravlja, smatramo korisnim razviti nacionalni program prevencije kroničnih bolesti kroz promociju zdravih stilova života te nastaviti podupirati projekte nevladinih organizacija koje rade na istom cilju.

$S$ ponosom ističemo da je tijekom šest godina rada Udruge u projektima sudjelovalo više od 300 volontera s više od 60000 volonterskih sati, te s preko 3000 uključenih sudionika.

Posebna zahvala svima koji su sudjelovali u našim aktivnostima, onim spomenutim ovdje, ali i mnogim drugima koje nismo posebno izdvajali.

\section{Literatura}

1. Vrhovac B i sur. 2008 (4.izdanje) Interna medicina, Zagreb, Naklada Ljevak; 568606; 662- 666; 863-874.

2. Karakaš S. Uticaj programiranih tjelesnih aktivnosti na kontrolu i redukciju poremećaja zdravlja, V međunarodni seminar " Uloga sporta u očuvanju zdravlja" Zbornik radova.

3. O'Donnell M, Mente A, Yusuf S. Sodium intake and cardiovascular health, Circ Res. 2015;116(6):1046-57.

4. Grandner MA, Jackson NJ, Pak VM, Gehrman PR. Sleep disturbance is associated with cardiovascular and metabolic disorders, J Sleep Res. 2012;21(4):427-33.

5. Keller A, Litzelman K, Wisk LE i sur. Does the perception that stress affects health matter? The association with health and mortality, Health Psychol. 2012;31(5):677-84.

6. Popis stanovništva, kućanstava i stanova u Republici Hrvatskoj 2011. godine.; DrŽavni zavod za statistiku (2013).

7. WHO: GLOBAL STATUS REPORT on noncommunicable diseases 2014

8. http://www.who.int/features/2013/japan_blood_pressure/en/

9. Iso H, Shimamoto T, Naito Y i sur. Effects of a Long-term Hypertension Control 
Program on Stroke Incidence and Prevalence in a Rural Community in Northeastern Japan, Stroke.1998;29(8):1510-8.

10. Ivkovic J, Njavro L, Mašić M i sur. Stroke risk factor prevalence survey at world stroke day in Zagreb, Acta Clin Croat. 2014;53(Suppl)(1);93.

11. Olweus D, 1998. Nasilje među djecom u školi, Zagreb, Školska knjiga.

12. Mrak M, Ozjaković M, Mašić M i sur. Bullyng prevention, Med Fam Croat 2015;23(1);110.

\section{Six Years of Public Health Activities of the Association of People's Health "Andrija Štampar"}

\section{Summary}

The Association of Public Health Andrija Štampar (hereinafter: the Association) was founded in the year 2009 within the Faculty of Medicine of the University of Zagreb. Main goals of the Association are the promotion of awareness about public and people's health and humanity; the promotion of healthy lifestyles; and the prevention of diseases. The Association works strongly on the promotion of personal and people-centred medicine; non-violent behaviour; and social equality. The Association gathers medical students, physicians and other academic citizens through a multidisciplinary approach.

Members of the Association strongly promote the learning of Andrija Štampar, who said that a person was not just a physical and a mental being, but a spiritual and a social being as well. Every activity of the Association has therefore been developed through this prism. We single out the following projects: Andrija Štampar Days; Be cool, don't be a bully; Health to all; and the projects commemorating the World Brain Day, the World Stroke Day, and other important public health dates with partner associations.

During six years, we have had more than 300 volunteers having worked more than 60,000 volunteer's hours, and more than 3,000 beneficiaries.

Keywords: Association of Public Health Andrija Štampar; public health; humanity; Andrija Štampar; multidisciplinary approach; volunteers.

Jakov Ivković, dr. med.

Udruga narodnog zdravlja "Andrija Štampar"

Šalata 4/I, 10000 Zagreb

jakov.ivko@gmail.com 